\title{
Coagulant proteins identified in Mustard: a potential water treatment agent
}

\author{
I. Bodlund · A. R. Pavankumar • R. Chelliah • \\ S. Kasi · K. Sankaran • G. K. Rajarao
}

Received: 12 June 2012/Revised: 21 January 2013/Accepted: 17 March 2013/Published online: 16 April 2013

(C) Islamic Azad University (IAU) 2013

\begin{abstract}
The use of natural coagulant protein in drinking water treatment has been discussed for a long time, though the method is still not in practice, probably due to limited knowledge and availability of material. In the present work, different Mustard varieties were tested for the presence of coagulant protein compared with Moringa seed extract and their potential application in water treatment. The coagulation activity of the protein extract was measured using synthetic clay solution as well as water from pond. The protein content was determined by Bradford method, molecular mass determined by Sodium dodecyl sulfate-polyacrylamide gel electrophoresis, and peptide sequence was analyzed by Mass spectrometry. Extract of Mustard (large) and Moringa seed showed coagulation activity of $\cong 70$ and $\cong 85 \%$ after $90 \mathrm{~min}$, respectively. Interestingly, seed extracts from other Mustard varieties had coagulation activity after heat activation at $95{ }^{\circ} \mathrm{C}$ for $5 \mathrm{~h}$. However, the coagulation activity of Mustard seed extract against turbid pond water was higher $(\cong 60 \%)$ compared to Moringa seed extract ( $\cong 50 \%)$. The peptide sequence analysis of 6.5 and $9 \mathrm{kDa}$ proteins was found to be homologous to Moringa coagulant protein and napin3, respectively. To our knowledge, this could be the first report on Mustard seed having coagulant protein. The coagulation activity of Mustard (large) against highly turbid pond water suggested that it could be a potential natural coagulant for water treatment.
\end{abstract}

I. Bodlund · A. R. Pavankumar · G. K. Rajarao ( $\square)$ School of Biotechnology, Royal Institute of Technology, AlbaNova University Centre, 10691 Stockholm, Sweden e-mail: gunar@biotech.kth.se

I. Bodlund · R. Chelliah · S. Kasi - K. Sankaran Centre for Biotechnology, Anna University, Chennai 600025, India
Keywords Brassica $\cdot$ Napin - Moringa coagulant protein . Peptide sequence $\cdot$ Thermo-tolerant

\section{Introduction}

Poor quality of drinking water and sanitation are the world's major causes of preventable morbidity and mortality due to water- and food-borne infections. Generally, drinking water treatment protocols consist of two steps: clarification and disinfection. Commonly, alum (aluminum sulfate) is used as a flocculating agent, as it is efficient and relatively cost-effective in developed countries; while disinfection is achieved by the addition of chemical disinfectants like chlorine-based compounds. However, prolonged usage of such chemicals causes serious adverse health effects like autonomous and central nervous system disorders including Alzheimer's disease (Crapper et al. 1973; Martyn et al. 1989), reproductive impairments, and different types of cancers by releasing physiologically incompatible reactive species or by-products into water (Morris et al. 1992). Moreover, treatment of highly turbid water requires a few proteolytic additives along with alum making it an expensive process. Such complicated methods are difficult to adopt, especially in poor or developing countries, where cost-effective and simple drinking water treatment methods are needed. Therefore, usage of safe, traditional or conventional water treatment agents from natural sources becomes essential.

The most extensively studied traditional water treatment agents such as seed extracts of Moringa oleifera (MO) have been reported to show high coagulation activity (Jahn 1988; Muyibi and Evison 1995; Ndabigengesere et al. 1995) and antimicrobial property (Ghebremichael et al. 2005; Fahey 2005; Anwar et al. 2007). Further, it can be 
used for the reduction of organic carbon, color, aromatic, and humic acid content (Santos et al. 2012). The coagulation activity of other plant materials from Cactus latifaira (Diaz et al. 1999), vegetable tannins (Özacar and Şengil 2003), bean (Phaseolus vulgaris sp.) (Antov et al. 2010), red bean (Phaseolus vulgaris sp.), sugar maize and red maize (Zea mays sp.) (Gunaratna et al. 2007), Jatropha curcas (Pritchard et al. 2009; Abidin et al. 2013), Nirmali seeds (Strychnos potatorum) (Babu and Chaudhuri 2005), chestnut and acorn (Šćiban et al. 2009) and Cassia angustifolia (Sanghi et al. 2002) has been reported. Although several natural materials are reported to be potent coagulant agents, the usage has not become widespread, probably due to limited knowledge and scientific reports on point-ofuse technology (Yin 2010). Considering the geographical locations, source, abundance and cost, the need for finding new environmentally friendly and safe materials with such value-added advantages is of central importance for water treatment.

A preliminary study from our group evaluated new potential coagulants from plant materials in Southern India and found that Mustard possesses coagulation activity comparable to Moringa seed extract. The objective of the present study was to evaluate different varieties of Mustard seed extracts and cake for its coagulation property against synthetic clay solution and turbid water from a pond in Chennai, India. The protein content, molecular mass of the protein and thermo-stability between different Mustard types of seed extracts were evaluated. Mass spectrometric analysis was performed to identify the active coagulant protein from Mustard seed extract and compared with Moringa coagulant protein. The experimental part of this study was performed during 2011 in India and Sweden.

\section{Materials and methods}

Preparation of seed extracts and coagulation activity analysis

Three types of Mustard seed and a Mustard cake belonging to Brassicaceae family: Mustard large (MusL; Brassica sp.), Mustard Small (MusS; Brassica sp.), Mustard Yellow (MusY; Sinapsis sp.), were purchased from Saravana stores, Chennai, India, while the Mustard Cake (MusC, Brassica sp.) was obtained from an oil factory in India. The coagulation activity was compared with $M$. oleifera (MO) seeds purchased from Agri seed shop, India. Crude extracts were made from the above mentioned seeds in the laboratory of Centre for Biotechnology, Chennai, India, at room temperature $\left(\sim 30{ }^{\circ} \mathrm{C}\right)$ as described by Ghebremichael et al. (2005) and the powder was then mixed with distilled water to obtain a $5 \%(\mathrm{w} / \mathrm{v})$ suspension. The insoluble material was separated after centrifugation and the resulting clear supernatant was referred as crude extract (CE). After preliminary analysis, the CEs were transported to School of Biotechnology, Royal Institute of Technology $(\mathrm{KTH})$, Stockholm, Sweden for further analysis.

Coagulation activity was tested against $1 \%$ kaolin (Merck) clay solution as described earlier (Ghebremichael et al. 2005). In the assay, $10 \mu \mathrm{l}$ of $\mathrm{CE}$ was added to clay solution to make a final volume of $1 \mathrm{ml}$ with clay solution. The absorbance at $500 \mathrm{~nm}\left(\mathrm{~A}_{500}\right)$ was measured with a spectrophotometer, instantly after mixing the clay solution and CEs at 0 min and the absorbance was measured in 30min time intervals up to maximum $120 \mathrm{~min}$. The percentage of coagulation activity was calculated using the formula:

$\frac{t_{0}-t}{t_{0}} * 100$

where $t_{0}$ is the $\mathrm{A}_{500}$ at $0 \mathrm{~min}$ and $t$ refers to the final absorbance.

Protein profile analysis

Protein content of the CEs prepared from above-mentioned seeds was estimated using protein-dye binding method (Bradford 1976), and a standard curve was plotted using known concentrations of Bovine Serum Albumin (BSA). Sodium dodecyl sulfate-polyacrylamide gel electrophoresis (SDS-PAGE) analysis was performed (Laemmli 1970; Fling and Gregerson 1986), and the resolved proteins were stained with Coomassie Brilliant Blue R250.

Thermo-stability/activation of coagulant proteins

In order to analyze the stability/activation of coagulant proteins, the CEs were heated at $95{ }^{\circ} \mathrm{C}$ for $5 \mathrm{~h}$, and coagulation activity was tested. After heat treatment, the samples were centrifuged and the clear solution was used. Protein content and protein profiles before and after the heat treatment were analyzed and compared.

Mass spectrometric analysis of proteins

Protein bands $\sim 6.5$ and $9 \mathrm{kDa}$ from $10 \%$ SDS-PAGE were excised carefully and processed according to Ghebremichael et al. (2005) with little modifications. The gel slices were treated with $35 \%$ acetonitrile (ACN) and $50 \mathrm{mM}$ Ammonium bicarbonate followed by $100 \% \mathrm{ACN}$ for $5 \mathrm{~min}$ and then digested with $20 \mathrm{ng} / \mu \mathrm{l}$ of trypsin in $50 \mathrm{mM}$ Ammonium bicarbonate for $16 \mathrm{~h}$. Mass spectra were acquired for these in-gel trypsin digested samples using Xevo ${ }^{\mathrm{TM}}$ QT of Mass Spectrometer (Waters, USA). The protein sequence information and other details were obtained from SwisProt and UniProt. 
Coagulation activity against turbid pond water

In order to compare the coagulation activity of Moringa and Mustard large against turbid pond water, CEs of these two seeds were added to the water. Highly turbid water was collected from a pond in Maduravoil, Chennai, India (drinking water source to local community) for measuring the coagulation activity. MO and MusL CEs (220 mg of seed powder/liter) were added in a beaker containing turbid water and mixed well. Initial absorbance was measured at $t=0$ and at every 60 min time interval $\left(\mathrm{A}_{500}\right)$ up to $3 \mathrm{~h}$. Pond water alone served as the control and had an initial absorbance of around 1.6.

\section{Results and discussion}

A recent study conducted by our group with more than 100 different plant materials tested for coagulation activity, revealed good scores for Mustard seeds. In the present investigation, different Mustard varieties were evaluated for their coagulation property; thermo-stability and identification of the protein responsible for coagulation activity were illustrated. Further, crude extracts (CEs) were tested against turbid water obtained from a pond in Chennai, India. The results from this investigation are discussed in the following sections.

\section{Coagulation activity of seed extracts}

Among the different varieties of Mustard crude extracts, only Mustard large (MusL) showed $\cong 70 \%$ of coagulation activity after $90 \mathrm{~min}$, as compared to $\cong 85 \%$ of $M$. oleifera (MO); whereas clay solution alone revealed $20 \%$ of activity. The time kinetics of the coagulation activity of MusL in comparison with MO is shown in Fig. 1. Mustard Small (MusS) showed lower activity ( $\cong 60 \%$ ) than MusL,

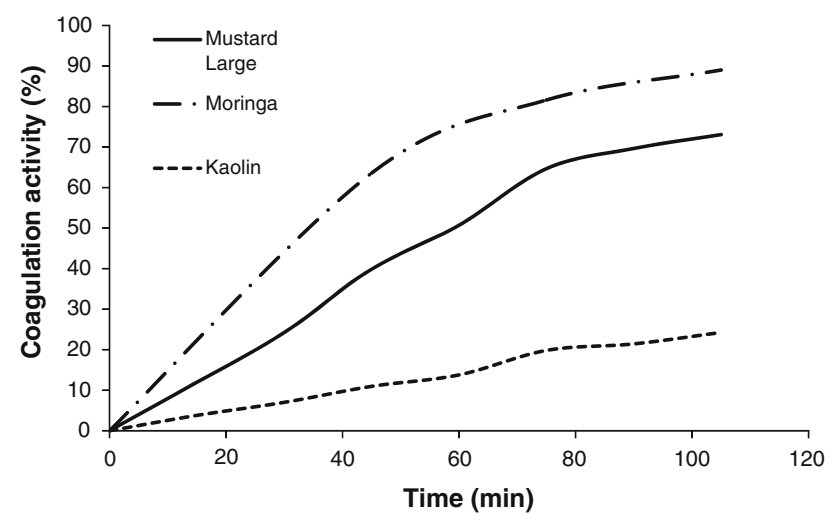

Fig. 1 Time kinetics of coagulation activity using crude extracts of Mustard large and Moringa seeds. Kaolin clay alone was used as a negative control whereas Mustard Cake (MusC) and Mustard Yellow (MusY) exhibited 45 and $25 \%$ coagulation activity, respectively. Moreover, various concentrations of the CEs (1-125 $\mu \mathrm{g} / \mathrm{ml}$ protein) were tested for coagulation activity and approximately $20-30 \mu \mathrm{g} / \mathrm{ml}$ protein showed the highest activity (data not shown). There are other plant materials such as Jatropa curcus and Phaseolus vulgaris that possess coagulation activity have been reported and are considered to be a potential water treatment agent (Abidin et al. 2013; Antov et al. 2010, 2012). However, the coagulation activity varies between the types of seed material used, extraction methods, initial turbidity of water, mixing, suspended particles, and ions present in the water samples (Okuda et al. 2001; Ghebremichael et al. 2005; Marobhe et al. 2007a; Abidin et al. 2013). Moreover, information on the exact nature of coagulant agent from other plant materials is scarce and needs further investigation. In this study, Mustard has been identified as a new plant material showing coagulation activity against synthetic clay solution prepared with tap water.

\section{Protein profile analysis}

The protein content of the four different Mustard crude extracts were estimated and found that MusY possesses the highest protein content of $4.0 \mathrm{mg} / \mathrm{ml}$ compared to that of $0.9 \mathrm{mg} / \mathrm{ml}$ of MusS, $2.9 \mathrm{mg} / \mathrm{ml}$ of MusL, and $2.1 \mathrm{mg} / \mathrm{ml}$ of MusC (Table 1). The SDS-PAGE profile of MusY, MusL, and MusS, as can be seen in Fig. 2, appears to be very similar to one another. Abundant protein bands of comparable quantities were observed below $14 \mathrm{kDa}$ (marked with arrows). The protein profile was determined immediately after the preparation of crude extract and upon storage as can be seen in Figs. 2 and 4, respectively. It is noteworthy that there are differences between the protein profiles of MusL. Although the same extract was used in both the cases, the differences could have various explanations apart from the possible variations in the water and chemicals used for the preparation of buffer solutions. It could be more likely that some proteins might have degraded during storage and transportation of samples to

Table 1 Protein content in various types of Mustard seeds (crude extracts) before and after heat activation

\begin{tabular}{llll}
\hline Crude extract & \multicolumn{2}{l}{ Protein content $(\mathrm{mg} / \mathrm{ml})$} & \multirow{2}{*}{$\begin{array}{l}\text { Reduction } \\
(\%)\end{array}$} \\
\cline { 2 - 3 } & $\begin{array}{l}\text { Before heat } \\
\text { activation }\end{array}$ & $\begin{array}{l}\text { After heat } \\
\text { activation }\end{array}$ & \\
\hline Mustard Yellow (MusY) & 4.1 & 1.1 & 71.9 \\
Mustard Large (MusL) & 2.9 & 2.7 & 8.0 \\
Mustard Cake (MusC) & 2.1 & 1.1 & 47.6 \\
Mustard Small (MusS) & 0.9 & 0.8 & 18.3 \\
\hline
\end{tabular}




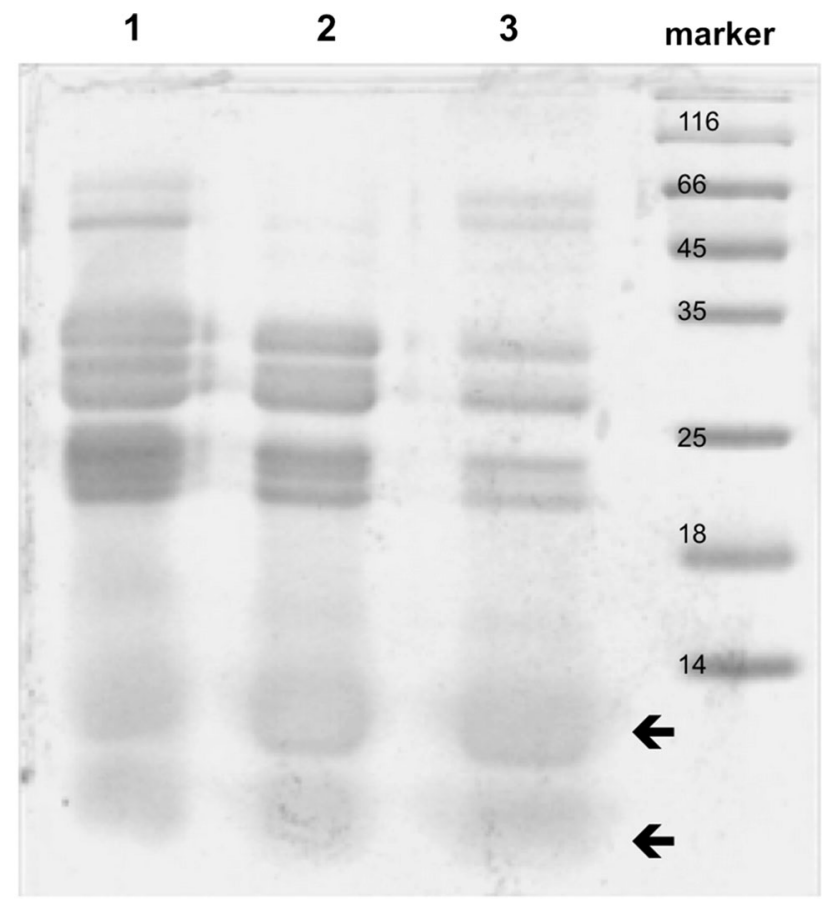

Fig. 2 Protein profiles of crude extracts (CE) of three varieties of Mustard seeds resolved on $10 \%$ SDS-PAGE. Lane 1 Mustard Yellow, 2 Mustard Small, 3 Mustard Large. Marker (Thermo Fisher Scientific) with a size range of $14.4-116 \mathrm{kDa}$

Sweden. It cannot be ruled out the possibility of degradation of some of the proteins that are sensitive to temperature, proteolytic cleavage and storage of crude extracts for long time. On the other hand, it is worth mentioning that the protein profiles showing $<14 \mathrm{kDa}$ were stable in all the crude extracts used in the analysis.

However, only MusL showed coagulation activity against synthetic clay solution, whereas seed extracts from other Mustard varieties did not show considerable activity as compared with MO (data not shown). This observation leads to many interesting queries to find out the variations in coagulation activity and the proteins responsible for such activity. The coagulant protein from the seed extract of $\mathrm{MO}$ reported widely to possess a molecular mass between 4 and $14 \mathrm{kDa}$ (Ndabigengesere et al. 1995; Broin et al. 2002) and is stable at high temperature (Ghebremichael et al. 2005), therefore one might assume that the protein profile of Mustard showing protein bands below $14 \mathrm{kDa}$ could exhibit the coagulation activity.

\section{Thermo-stability/activation of coagulant protein}

Thermo-stability/activation of all the Mustard seed extracts and MusC was determined by heating them at $95{ }^{\circ} \mathrm{C}$ for $5 \mathrm{~h}$. Even after prolonged exposure to high temperature, the coagulation activity of MusL remained the same as before, as seen in Fig. 3. Interestingly, MusY and MusC

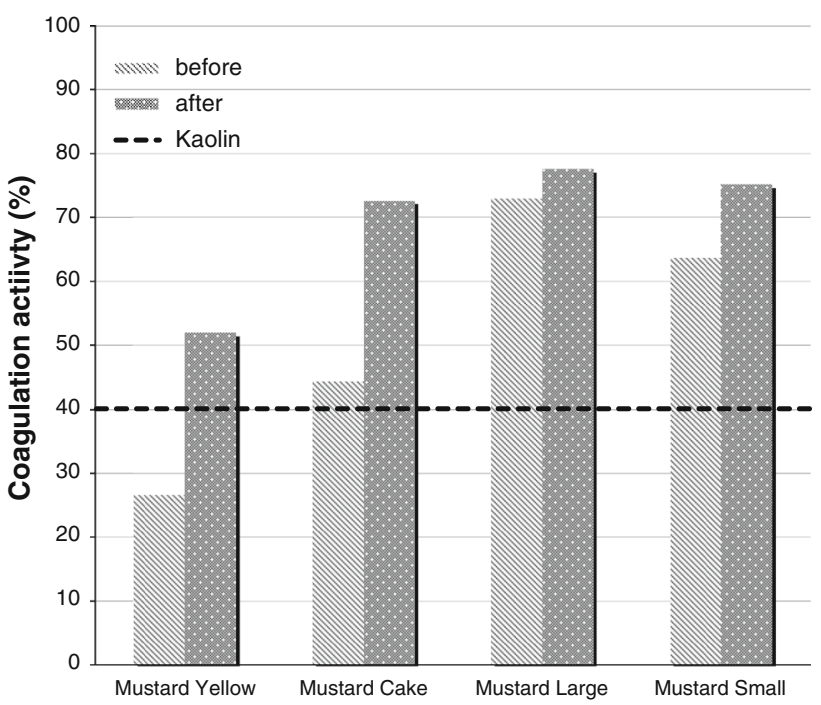

Fig. 3 Coagulation activity of crude extracts from various Mustard seeds before and after thermo-activation was measured after $90 \mathrm{~min}$. The kaolin clay used as a negative control is marked with a dotted line

extracts gained activity to the extent of $25-30 \%$ upon heating, suggesting the removal of some hindrance for the coagulation activity. In the case of MusC and MusY, the hindrance could have been partial and it was removed upon heating. MusS and MusL, however, were showing only $5-10 \%$ increase in the activity even after the heat treatment. It is observable that the clay sedimentation was different between the experiments performed in India (Fig. 1) and in Sweden (Fig. 3). This could be attributed to the differences in the physicochemical properties of the different tap water samples used in preparing the clay solutions.

The thermo-stability of the coagulant protein is in accordance with previous studies conducted on Moringa seed (Ghebremichael et al. 2005) and also the case of red bean, sugar maize and red maize (Gunaratna et al. 2007). Similar properties have also been described in crude extracts, as well purified proteins of Vigna unguiculata and Parkinsonia aculeata seeds, where the coagulant protein around $6 \mathrm{kDa}$ was found to be thermo-stable (Marobhe et al. 2007b). The enhanced coagulation activity especially after heat treatment seen in MusY and MusC is an interesting observation and first reported in this study. Though the mechanism for this behavior is not apparent, it would be worth investigating this new phenomenon. To further extend the study, the protein content and profiles of the extracts before and after heating were investigated.

Protein profile after heat treatment

After treating the CEs at $95{ }^{\circ} \mathrm{C}$ for $5 \mathrm{~h}$, the protein content and profile for all extracts were investigated and compared. 
The difference in the protein content indicates that some of the proteins might have been denatured during the heating process (Table 1). Interestingly, there was a correlation between the reduction in protein content and the difference in coagulation activity before and after heating of extracts. When the reduction of protein content in the solution was high, as in MusC ( $\cong 48 \%)$, the increase of coagulation activity was higher after heat treatment. This observation was also applicable for MusY, which showed $\cong 72 \%$ reduction of protein after heating and twofold increase in coagulation activity could be seen to the extent of $50 \%$. MusL and MusS, whose coagulation activity did not increase drastically, on the other hand did not lose much protein upon heating.

Differences in protein profiles between CEs with and without heat treatment were analyzed on SDS-PAGE (Fig. 4).

The most interesting proteins pertaining coagulation activity have been marked with arrows (Fig. 4). The proteins with the molecular mass of $42,24,14,9$, and $6.5 \mathrm{kDa}$ were dominant in all the CEs (except MusL) before heat treatment while after heating, only the 9 and $6.5 \mathrm{kDa}$ proteins were observed with similar intensities. This could possibly indicate that the 42,24 , and $14 \mathrm{kDa}$ proteins might have been denatured upon heating. Altogether this information suggests that $9 \mathrm{kDa}$ protein might be responsible for the coagulation activity in the CEs tested in this study. However, the loss of proteins other than $9 \mathrm{kDa}$ upon heating would support the hypothesis of possible proteinprotein complex inhibiting the coagulation activity. As suggested by Ceciliani et al. (1994), the heat stability of the coagulating protein is advantageous in the purification step, thus one could avoid using expensive matrix, buffer salt, and long purification protocols. As can be seen, the coagulation proteins are already purified to near homogeneity by a simple heating procedure.

In earlier reports, Moringa coagulant protein identified as a $6.5 \mathrm{kDa}$ protein possesses three alpha helices structure by computer simulation modelling studies and has coagulation activity (Ghebremichael et al. 2005; Broin et al. 2002; Suarez et al. 2005; Okoli 2012). Since two interesting protein bands of 9 and $6.5 \mathrm{kDa}$ (Fig. 4) found in this study, the identity of these polypeptides by peptide sequence using Mass spectrometer was investigated.

Mass spectrometric analysis of protein

The significant protein bands of MusL (marked with arrows in Fig. 4) that were presumed to have a role in coagulation activity were analyzed by MALDI-TOF to disclose their identity. The MS/MS analysis of these two trypsin digested proteins revealed six peptides: a 19 amino acid peptide (QAVQLTHQQQGQVGPQQVR) from $\sim 6.5 \mathrm{kDa}$ band and 5 peptides (KVCNIPQVSVCPFQK; QQQGQQGQQ LQQVISR; GQQGQQLQQVISR; QQVRQQQ GQQG QQLQQVISR; GPQGPQQRPPLLQQCCNELHQEEPLCV CPTLK) from $\sim 9 \mathrm{kDa}$ band.

The 19 amino acid peptide obtained from $6.5 \mathrm{kDa}$ protein band showed sequence coverage of $37 \%$ with flocculent protein of $M$. oleifera (MO2.1; SwissProt ID: P24303). As depicted in Fig. 5a, this 19 residue peptide matched perfectly between 30 and 48 amino acid residues of MO2.1 with a score of 242 . Hence, this could be confirmed as a flocculation protein from MusL, which could be responsible for coagulation activity.

The $9 \mathrm{kDa}$ protein band was identified with 5 peptides correlated with $14.5 \mathrm{kDa}$ napin3 protein (SwissProt ID: P80208), with a sequence coverage of $54 \%$ (Fig. 5b).
Fig. 4 Protein profiles of crude extracts from various Mustard seeds before and after heating (marked with $\Delta$ ). About $10 \mu \mathrm{g}$ of the proteins were resolved in each lane. Marker used was low molecular weight marker from Sigma (6.5-66 kDa)

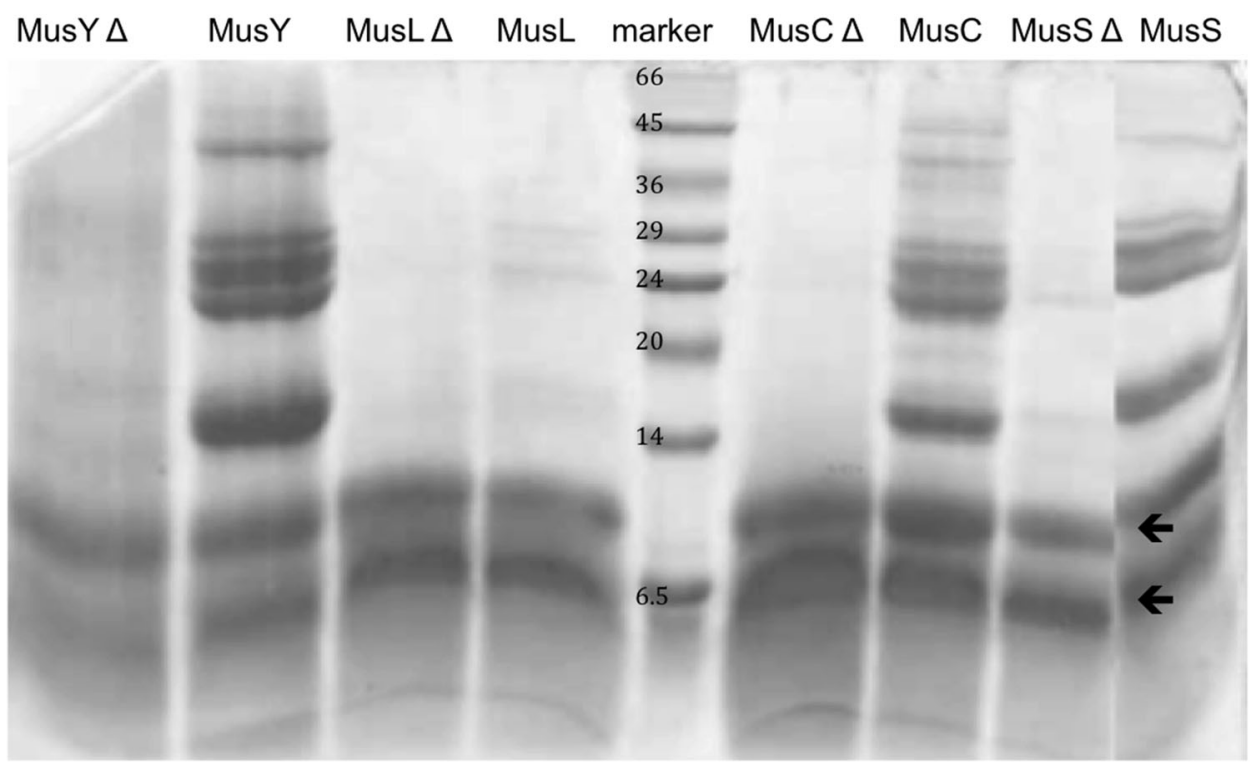




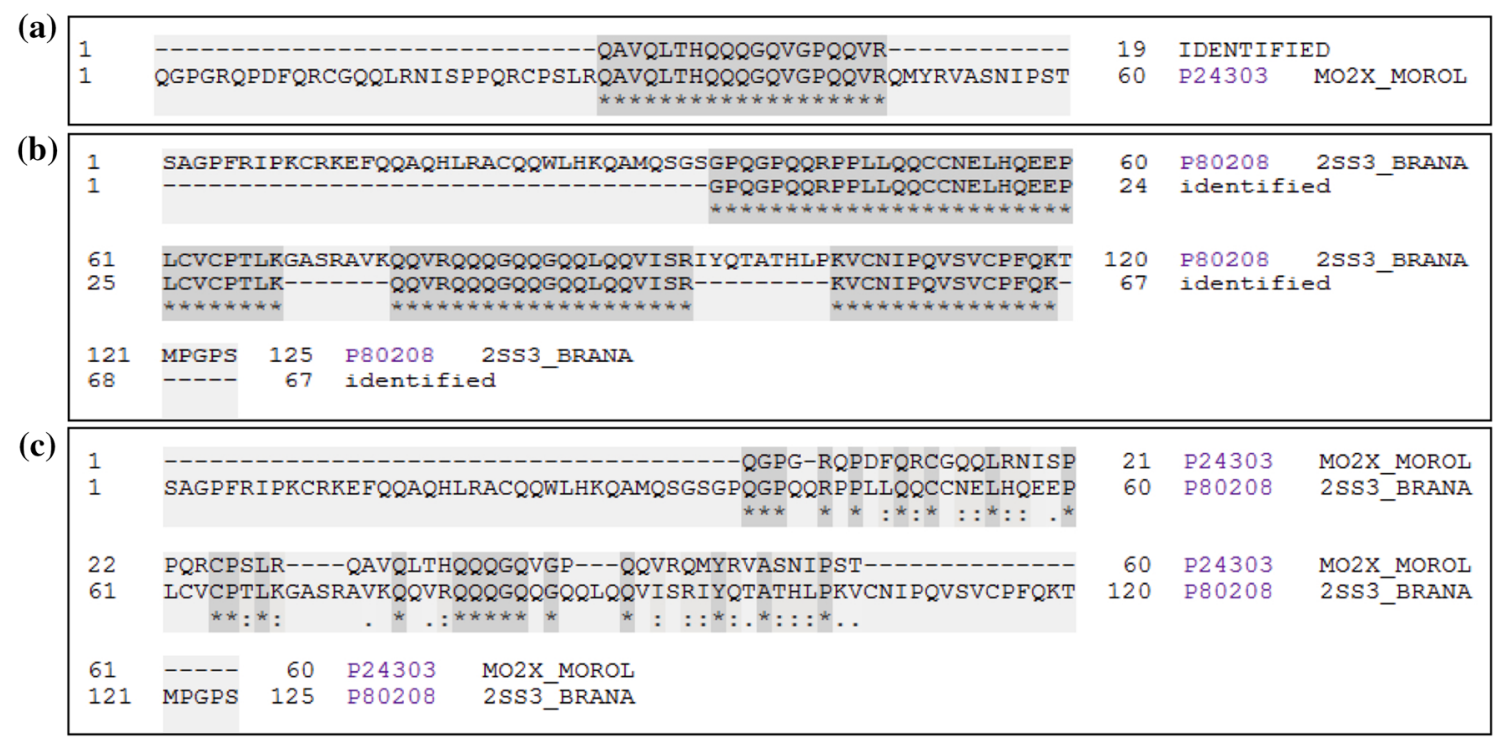

Fig. 5 MALDI-TOF-MS/MS analysis of 6.5 and $9 \mathrm{kDa}$ protein bands. Mustard seed extract excised from SDS-PAGE as shown in Fig. 3. The in-gel protein eluted and trypsin digested peptides show sequence similarity with well-known proteins: (a) identified peptide of 19 amino acids completely matched with the sequence of Moringa

Sequence alignment analysis between the identified peptides and the seed storage protein, napin3, showed a high score of 901 with 67 residue matches, indicating its high homology. The identified 32 amino acid peptide, GPQ GPQQRPPLLQQCCNELHQEEPLCVCPTLK, matched between 37 and 69 bases, the 20 amino acid peptide, QQVRQQQ GQQGQQLQQVISR, matched between 77 and 96 residues, and the third 15 amino acid peptide, KVCNIPQVSVCPFQK, matched between 106 and 127 amino acid residues of napin3 large chain.

Further, sequence alignment between the two seed storage proteins of Moringa (P24303, MO2X_MOROL) and napin3 (P80208, 2SS3_BRANA) of Brassica species showed a match of 23 residues (Fig. 5c), indicating its plausible association to possess synergetic coagulation activity in mustard. Suarez et al. (2005) reported a computer simulated hypothetical model of coagulant protein of MO2.1 using napin3 as a homolog. The fact that the seed storage protein is acting as a coagulating agent is quite useful, as the abundant protein in commonly used Mustard would provide a cheaper source for commercial exploitation.

Effect of coagulant protein on turbid pond water

In order to evaluate the efficiency of the MusL seed extract as a water treatment agent, the seed extracts were tested against turbid pond water and compared with MO. Both MO and MusL showed coagulation activities against highly turbid water collected from pond. Interestingly, MO oleifera coagulation protein, MO2.1 (MOCP). Similarly (b) the 67 amino acids were exactly matched with napin 3 protein sequence. c Sequence alignment between MOCP and napin3 showing 23 amino acid residues in common

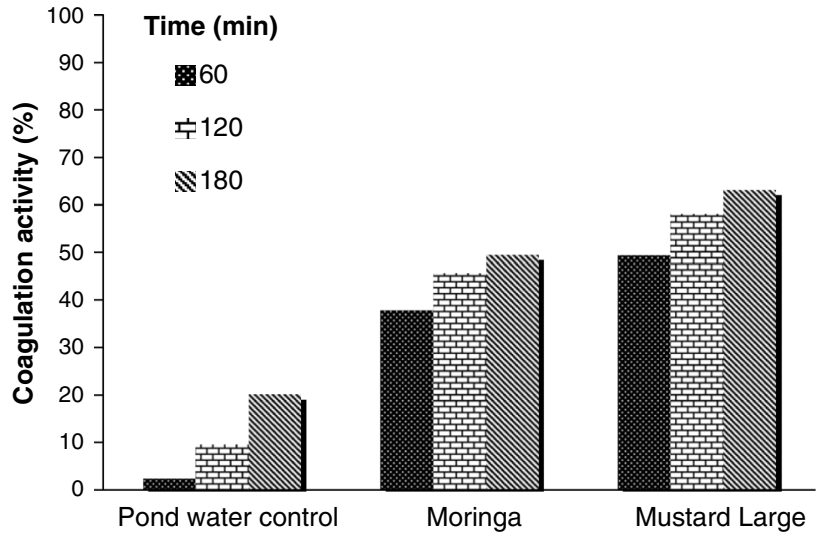

Fig. 6 Coagulation activity of crude extract from Moringa and Mustard Large seeds in turbid pond water. Pond water alone was used as control. Samples for measurement of turbidity are taken after 60 , 120 , and $180 \mathrm{~min}$

showed higher coagulation activity $(\cong 85 \%)$ against synthetic kaolin clay solution than MusL ( $\cong 70 \%)$ (Fig. 1). On the other hand, MusL showed better coagulation activity $(\cong 60 \%)$ than $\mathrm{MO}(\cong 50 \%)$ in pond water (Fig. 6) indicating the possible variability in efficiencies of plant coagulant proteins according to the initial turbidity, nature of clay, and other suspended particles. This is very unlikely in this study since there was a difference between Moringa and Mustard coagulant protein. However, it could be speculated that Mustard has 9 and $6.5 \mathrm{kDa}$ proteins, which has sequence similarity with napin 3 and Moringa coagulant protein (MO2.1), respectively. Napin3 has homolog with MO2.1 protein thereby it might be that 
Mustard seed protein has synergistic effect of coagulation activity. Further studies are required to confirm the protein responsible for coagulation activity from Mustard seed.

To our knowledge, this is the first report on coagulant protein identified in Mustard seed extracts. The low cost of the raw material and the availability of Mustard throughout the year would be an added advantages, and Mustard large seed could be a good alternative to Moringa seed as a natural coagulant.

\section{Conclusion}

Present study revealed the presence of coagulant proteins in Mustard seed extracts. The coagulant proteins are thermo-stable even after heat treatment of $95{ }^{\circ} \mathrm{C}$ for $5 \mathrm{~h}$ from the seed extracts of MusL and MusS. The heat treatment improved the coagulation activity of MusY and MusC significantly. Coagulant proteins with sizes of approximately 9 and $6.5 \mathrm{kDa}$ have been identified and the peptide sequence analysis confirms the presence of coagulant protein with approximately $6.5 \mathrm{kDa}$ protein similar to MO2.1 and a $9 \mathrm{kDa}$ protein similar to napin3 seed storage protein. The napin3 peptide sequence has homology with MO2.1 suggesting that both 6.5 and $9 \mathrm{kDa}$ proteins could be involved in coagulation activity. It could be evidenced by having higher coagulation activity in natural clay water of Mustard seed extract suggesting that this might be a good complement to Moringa as a natural coagulant in drinking water treatment.

Acknowledgments The authors wish to acknowledge the Erasmus Mundus India4EU scholarship program (Lot 13) and Sida (Swedish International Development Cooperation Agency)(SWE-2007-401) for financial support and Vaibhav Srivastava, School of Biotechnology, $\mathrm{KTH}$, for helping in MALDI analysis.

\section{References}

Abidin ZZ, Shamsudin NSM, Madehia N, Sobria S (2013) Optimisation of a method to extract the active coagulant agent from Jatropha curcas seeds for use in turbidity removal. Ind Crops Prod 41:319-323

Antov MG, Šćiban MB, Petrović NJ (2010) Proteins from common bean (Phaseolus vulgaris) seed as a natural coagulant for potential application in water turbidity removal. Bioresour Technol 101(7):2167-2172

Antov MG, Šćiban MB, Prodanović JM (2012) Evaluation of the efficiency of natural coagulant obtained by ultrafiltration of common bean seed extract in water turbidity removal. Ecol Eng 49:48-52

Anwar F, Latif S, Ashraf M, Gilani AH (2007) Moringa oleifera: a food plant with multiple medicinal uses. Phythér Res 21:17-25

Babu R, Chaudhuri M (2005) Home water treatment by direct filtration with natural coagulant. J Water Health 3(1):27-30
Bradford MM (1976) Rapid and sensitive method for quantitation of microgram quantities of protein utilizing principle of protein-dye binding. Anal Biochem 72:248-254

Broin M, Santaella C, Cuine S, Kokou K, Peltier G, Joet T (2002) Flocculent activity of a recombinant protein from Moringa oleifera lam seeds. App Microbiol Biotechnol 60(1-2):114-119

Ceciliani F, Bortolotti F, Menegatti E, Ronchi S, Ascenzi P, Palmieri S (1994) Purification, inhibitory properties, amino acid sequence and identification of the reactive site of a new serine proteinase inhibitor from oil-rape (Brassica Napus) seed. FEBS Lett 342(2):221-224

Crapper DR, Krishnan SS, Dalton AJ (1973) Brain aluminum distribution in Alzheimer's disease and experimental neurofibrillary degeneration. Science 180(85):511-513

Diaz A, Rincon N, Escorihuela A, Frenandez N (1999) A preliminary evaluation of turbidity removal by natural coagulants indigenous to Venezuela. Process Biochem 35:391-395

Fahey JW (2005) Moringa oleifera: a review of the medical evidence for its nutritional, therapeutic, and prophylactic properties. Part 1. Trees Life J 1:5

Fling SP, Gregerson DS (1986) Peptide and protein molecular weight determination by electrophoresis using a high-molarity tris buffer system without urea. Anal Biochem 155(1):83-88

Ghebremichael KA, Gunaratna KR, Henriksson H, Brumer H, Dalhammar G (2005) A simple purification and activity assay of the coagulant protein from Moringa oleifera seed. Water Res 39(11):2338-2344

Gunaratna KR, Garcia B, Andersson S, Dalhammar G (2007) Screening and evaluation of natural coagulants for water treatment. Water Sci Technol Water Supply 7(5-6):19-25

Jahn S (1988) Using Moringa seeds as coagulants in developingcountries. J Am Water Works Assoc 80(6):43-50

Laemmli UK (1970) Cleavage of structural proteins during the assembly of the head of bacteriophage T4. Nature 227(5259): 680-685

Marobhe N, Renman G, Jackson M (2007a) Investigation on the performance of local plant materials from coagulation of turbid river water. J Inst Eng Tanzania 8(3):50-62

Marobhe NJ, Dalhammar G, Gunaratna KR (2007b) Simple and rapid methods for purification and characterization of active coagulants from the seeds of Vigna unguiculata and Parkinsonia aculeata. Environ Technol 28(6):671-681

Martyn CN, Osmond C, Edwardson JA, Barker DJP, Harris EC, Lacey RF (1989) Geographical relation between Alzheimer's disease and aluminium in drinking water. Lancet 333(8629):61-62

Morris RD, Audet AM, Angelillo IF, Chalmers TC, Mosteller F (1992) Chlorination, chlorination by-products, and cancer-a metaanalysis. Am J Public Health 82(7):955-963

Muyibi S, Evison L (1995) Optimizing physical parameters affecting coagulation of turbid water with Moringa-Oleifera seeds. Water Res 29(12):2689-2695

Ndabigengesere A, Narasiahn K, Talbot B (1995) Active agents and mechanism of coagulation of turbid waters using MoringaOleifera. Water Res 29(2):703-710

Okoli C (2012) Development of protein-functionalized magnetic iron oxide nanoparticles: potential application in water treatment. Doctoral dissertation. Stockholm: KTH Royal Institute of Technology

Okuda T, Baes AU, Nishijima W, Okada M (2001) Coagulation mechanism of salt solution-extracted active component in Moringa oleifera seeds. Water Res 35:830-834

Özacar M, Şengil İA (2003) Evaluation of tannin biopolymer as a coagulant aid for coagulation of colloidal particles. Colloids Surf A Physicochem Eng Asp 229(1-3):85-96

Pritchard M, Mkandawire T, Edmondson A, O’Neill JG, Kululanga G (2009) Potential of using plant extracts for purification of 
shallow well water in Malawi. J Phys Chem Earth 34(13-16):799-805

Sanghi R, Bhatttacharya B, Singh V (2002) Cassia angustifolia seed gum as an effective natural coagulant for decolourisation of dye solutions. Green Chem 4(3):252-254

Santos AFS, Paiva PMG, Teixeira JAC, Brito AG, Coelho LCBB, Nogueira R (2012) Coagulant properties of Moringa oleifera protein preparations: application to humic acid removal. Environ Technol 33(1):69-75
Šćiban M, Klašnja M, Antov M, Škrbić B (2009) Removal of water turbidity by natural coagulants obtained from chestnut and acorn. Bioresour Technol 100:6639-6643

Suarez M, Haenni M, Canarelli S, Fisch F, Chodanowski P, Servis C (2005) Structure-function characterization and optimization of a plant-derived antibacterial peptide. Antimicrob Agents Chemother 49(9):3847-3857

Yin C-Y (2010) Emerging usage of plant-based coagulants for water and wastewater treatment. Process Biochem 45:1437-1444 